\title{
Prevalence and Characteristics of Shiga Toxin-Producing Escherichia coli from Healthy Cattle in Japan
}

\author{
HIDEKI KOBAYASHI, ${ }^{1,2 *}$ JUN SHIMADA,${ }^{3}$ MUNEO NAKAZAWA, ${ }^{1}$ TETSUO MOROZUMI, ${ }^{1}$ \\ TARJA POHJANVIRTA, ${ }^{2}$ SINIKKA PELKONEN, ${ }^{2}$ AND KOSHI YAMAMOTO ${ }^{1}$ \\ National Institute of Animal Health, 3-1-1, Kannondai, Tsukuba 305-0856, ${ }^{1}$ and Chiba Prefectural Institute of Animal \\ Health, 497, Iwatomi, Sakura 285-0072, ${ }^{3}$ Japan, and National Veterinary and Food Research Institute, Kuopio \\ Regional Laboratory, FIN-70701, Kuopio, Finland ${ }^{2}$
}

Received 5 June 2000/Accepted 20 October 2000

\begin{abstract}
The prevalence of Shiga toxin-producing Escherichia coli (STEC) in Japan was examined by using stool samples from 87 calves, 88 heifers, and 183 cows on 78 farms. As determined by screening with stx-PCR, the prevalence was $46 \%$ in calves, $66 \%$ in heifers, and $69 \%$ in cows; as determined by nested stx-PCR, the prevalence was $100 \%$ in all animal groups. Of the 962 isolates picked by colony stx hybridization, 92 isolates from 54 farms were characterized to determine their $O$ serogroups, virulence factor genes, and antimicrobial resistance. Of these 92 isolates, $74(80 \%)$ could be classified into $O$ serogroups; $50 \%$ of these 74 isolates belonged to $O$ serogroups $08,026,084,0113$, and 0116 and 1 isolate belonged to $\mathrm{O}$ serogroup 0157 . Locus of enterocyte effacement genes were detected in $24 \%$ of the isolates, and enterohemorrhagic $E$. coli (EHEC) $h l y A$ genes were detected in $72 \%$ of the isolates. Neither the bundle-forming pilus gene nor the enteropathogenic $E$. coli adherence factor plasmid was found. STEC strains with characteristics typical of isolates from human EHEC infections, which were regarded as potential EHEC strains, were present on $11.5 \%$ of the farms.
\end{abstract}

The importance of Shiga toxin (Stx)-producing Escherichia coli (STEC) has increased since a food-borne infection caused by enterohemorrhagic E. coli (EHEC) was first described (25). Cattle have been implicated as a principle reservoir of STEC $(3,5,31)$. The STEC strains are classified into a large number of O serogroups $(4,22)$. However, the majority of outbreaks and/or sporadic cases of hemorrhagic colitis and hemolytic uremic syndrome have been caused by members of only a few serogroups, such as O26, O111, and O157 (14, 26, 28). The Stx are known to be essential virulence factors of $\operatorname{EHEC~}(6,21)$, but the Stx alone may not be sufficient to cause disease (2). The virulence of STEC is known to be mediated through Stxs and attachment factors. The genes coding for these virulence-associated properties are located on phages, a pathogenicity island called the locus of enterocyte effacement (LEE), and plasmids $(1,9,15)$. In particular, genes of the LEE are almost always detected in EHEC and are always detected in enteropathogenic E. coli (EPEC) and attaching and effacing E. coli (AEEC), and they express the attaching and effacing (AE) lesion for enteroepithelial cells (9). The LEE consists of genes for adhering intimin (eae), translocated intimin receptor (tir), a type III secretion system, and other secreted proteins (9). These recently discovered mediators of AE lesions are often examined to characterize STEC strains isolated from human clinical samples (29).

The aims of the present study were to describe the prevalence of STEC in healthy cattle in the central part of Japan and to genetically characterize various virulence genes of the STEC strains isolated.

E. coli O157:H7 strains ATCC 43889, ATCC 43890, ATCC

\footnotetext{
* Corresponding author. Mailing address: National Institute of Animal Health, 3-1-1, Kannondai, Tsukuba 305-0856, Japan. Phone: 81298-387739. Fax: 81-298-387740. E-mail: reptile@niah.affrc.go.jp.
}

43894, and ATCC 35150, used as positive control strains for stx genes, were obtained from the American Type Culture Collection. E. coli 166, VR299-2, and EPEC108, used as positive control strains for intimin $\beta$, intimin $\varepsilon$, the bundle-forming pilus ( $b f p)$, and the "EPEC adherence factor" (EAF) plasmid $(1,19,24)$, were derived from the stock culture collection of the National Veterinary and Food Research Institute. E. coli Fuku-07, Oki-04, Sai-11, and Shizu-19, previously isolated from cattle in Japan and identified as O157:H7 strains, were used as reference strains.

A total of 358 rectal stool grab samples were collected from healthy dairy cattle ( 87 calves less than 5 months old, 88 heifers 5 to 12 months old, and 183 cows) on 78 farms located in a region of central Japan called the Kanto-Koshinetsu region between May and October 1998. All rectal stools were sampled by veterinarians from governmental animal hygiene centers. The samples were placed in cool room $\left(4\right.$ to $\left.8^{\circ} \mathrm{C}\right)$ and taken to the laboratory for immediate processing (usually within $24 \mathrm{~h}$ ). The stool samples were streaked on sorbitol-MacConkey agar (SMAC) (Eiken, Tokyo, Japan), and $1 \mathrm{~g}$ of each stool sample was enriched in $19 \mathrm{ml}$ of modified $E$. coli broth (mEC) (Eiken). Both SMAC plates and $\mathrm{mEC}$ were incubated at $37^{\circ} \mathrm{C}$ for 16 to $18 \mathrm{~h}$.

A $100-\mu 1$ aliquot of an enriched mEC culture (described above) was used for $s t x$-PCR (34). It was centrifuged at $13,500 \times g$ for $1 \mathrm{~min}$, and the pellet was washed with $1 \mathrm{ml}$ of phosphate-buffered saline. The bacterial sediment was resuspended in $100 \mu \mathrm{l}$ of distilled water and heated at $100^{\circ} \mathrm{C}$ for 5 min. Five microliters was used for stx-PCR performed with a pair of stx common PCR primers (Table 1) (34). (The positions of the stx conserved sequence primers for stx genes are as follows: sense primer VT com-u, positions 280 to 300; and antisense primer VT com-d, positions 778 to 797.) When a sample was negative in the $s t x$-PCR, $1 \mu$ l of the PCR mixture 
TABLE 1. Oligonucleotide probe and primers and PCR programs to amplify specific fragments from the various pathogenic genes in $E$. coli

\begin{tabular}{|c|c|c|c|c|c|c|c|}
\hline \multirow{2}{*}{$\begin{array}{l}\text { Oligonucleotide probe or } \\
\text { PCR primer (orientation) }\end{array}$} & \multirow{2}{*}{ Target gene(s) } & \multirow{2}{*}{ Sequence $\left(5^{\prime}-3^{\prime}\right)$} & \multicolumn{3}{|c|}{ Reaction temp $\left({ }^{\circ} \mathrm{C}\right)$} & \multirow{2}{*}{$\begin{array}{l}\text { Size of } \\
\text { product } \\
\text { (bp) }\end{array}$} & \multirow{2}{*}{ Reference } \\
\hline & & & Denaturation & Annealing & Extension & & \\
\hline $\begin{array}{l}\text { VT com (oligonucleotide } \\
\text { probe })^{a}\end{array}$ & stx 1 and $s t x 2$ & GAGCGAAATAATTTATATGTG & & & & & 34 \\
\hline $\begin{array}{l}\text { VT com-u (forward) } \\
\text { VT com-d (reverse) }\end{array}$ & stx 1 and $s t x 2$ & $\begin{array}{l}\text { GAGCGAAATAATTTATATGTG } \\
\text { TGATGATGGCAATTCAGTAT }\end{array}$ & $94(45)^{b}$ & $55(45)$ & $72(60)$ & 518 & 34 \\
\hline $\begin{array}{l}\text { VT com-nesF (forward) } \\
\text { VT com-nesR (reverse) }\end{array}$ & stx 1 and stx 2 & $\begin{array}{l}\text { CGGACAGTAGTTATACCAC } \\
\text { CTGCTGTCACAGTGACAA }\end{array}$ & $94(30)$ & $55(30)$ & $72(45)$ & 171 & 34 \\
\hline $\begin{array}{l}\text { VT1a (forward) } \\
\text { VT1b (reverse) }\end{array}$ & stx 1 & $\begin{array}{l}\text { CAGTTAATGTGGTGGCGAAG } \\
\text { CTGCTAATAGTTCTGCGCATG }\end{array}$ & $94(60)$ & $55(60)$ & $72(60)$ & 894 & 18 \\
\hline $\begin{array}{l}\text { VT2a (forward) } \\
\text { VT2b (reverse) }\end{array}$ & stx 2 & $\begin{array}{l}\text { CTTCGGTATCCTATTCCCGG } \\
\text { GGATGCATCTCTGGTCATTG }\end{array}$ & $94(60)$ & $55(60)$ & $72(60)$ & 478 & 18 \\
\hline $\begin{array}{l}\text { BFP1 (forward) } \\
\text { BFP2 (reverse) }\end{array}$ & $b f p$ & $\begin{array}{l}\text { GATTGAATCTGCAATGGTGC } \\
\text { GGATTACTGTCCTCACATAT }\end{array}$ & $94(60)$ & $57(60)$ & $72(60)$ & 597 & 30 \\
\hline $\begin{array}{l}\text { EAF1 (forward) } \\
\text { EAF25 (reverse) }\end{array}$ & EAF plasmid & $\begin{array}{l}\text { CAGGGTAAAAGAAAGATGATAA } \\
\text { TATGGGGACCATGTATTATCA }\end{array}$ & $94(60)$ & $57(45)$ & $72(60)$ & 399 & 8 \\
\hline $\begin{array}{l}\text { Ehly AF (forward) } \\
\text { Ehly AR (reverse) }\end{array}$ & EHEC-hly $A$ & $\begin{array}{l}\text { GCATCATCAAGCGTACGTTCC } \\
\text { AATGAGCCAAGCTGGTTAAGCT }\end{array}$ & $94(60)$ & $60(120)$ & $72(60)$ & 534 & 20 \\
\hline $\begin{array}{l}\text { eae-1 (forward) } \\
\text { eae-2 (reverse) }\end{array}$ & eae & $\begin{array}{l}\text { ACGTTGCAGCATGGGTAACTC } \\
\text { GATCGGCAACAGTTTCACCTG }\end{array}$ & $94(60)$ & $55(60)$ & $72(60)$ & 815 & 10 \\
\hline $\begin{array}{l}\text { Int- } \alpha \text { (forward) } \\
\text { Int-Ru (reverse) } \\
\text { Int- } \alpha \text { R (reverse) }\end{array}$ & eae & $\begin{array}{l}\text { CCTTAGGTAAGTTAAGT } \\
\text { TTTATTTGCAGCCCCCCAT } \\
\text { TGACTAGACTTATTATATTC }^{c}\end{array}$ & $95(45)$ & $45(60)$ & $72(60)$ & $\begin{array}{l}557 \\
588\end{array}$ & $\begin{array}{c}1 \\
\text { This study }\end{array}$ \\
\hline $\begin{array}{l}\text { Int- } \beta \text { (forward) } \\
\text { Int-Ru (reverse) }\end{array}$ & eae & $\begin{array}{l}\text { TAAGGATTTTGGGACCC } \\
\text { TTTATTTGCAGCCCCCCAT }\end{array}$ & $95(60)$ & $45(60)$ & $72(60)$ & 563 & 1 \\
\hline $\begin{array}{l}\text { Int- } \gamma \text { (forward) } \\
\text { Int-Ru (reverse) } \\
\text { Int- } \gamma \mathrm{R} \text { (reverse) }\end{array}$ & eae & $\begin{array}{l}\text { ACAAACTTTGGGATGTTC } \\
\text { TTTATTTGCAGCCCCCCAT } \\
\text { AGTTCATAGAACTATAATGGC }\end{array}$ & $95(45)$ & $55(60)$ & $72(60)$ & $\begin{array}{l}542 \\
571\end{array}$ & $\begin{array}{c}1 \\
\text { This study }\end{array}$ \\
\hline $\begin{array}{l}\text { Int- } \delta \text { (forward) } \\
\text { Int-Ru (reverse) }\end{array}$ & eae & $\begin{array}{l}\text { TACGGATTTTGGGGCAT } \\
\text { TTTATTTGCAGCCCCCCAT }\end{array}$ & $95(45)$ & $45(60)$ & $72(60)$ & 563 & 1 \\
\hline $\begin{array}{l}\text { SK-1 (forward) } \\
\text { LP-5 (reverse) }\end{array}$ & $e a e^{d}$ & $\begin{array}{l}\text { CCCGAATTCGGGACAAGCATAAGC } \\
\text { AGCTCACTCGTAGATGACGGCAAGCG }\end{array}$ & $94(45)$ & $65(45)$ & $72(120)$ & 2,608 & 19 \\
\hline $\begin{array}{l}\text { ESPA-F (forward) } \\
\text { ESPA-R (reverse) }\end{array}$ & esp $A$ & $\begin{array}{l}\text { ACTCGGTGTTTTTCAGGCTGC } \\
\text { TGAAATAGTTCTATATTG }\end{array}$ & $94(40)$ & $53(45)$ & $72(60)$ & $445^{e}$ & This study \\
\hline $\begin{array}{l}\text { ESPB-F (forward) } \\
\text { ESPB-R (reverse) }\end{array}$ & $\operatorname{esp} B$ & $\begin{array}{l}\text { GCCGTTTTTGAGAGCCAGAAT } \\
\text { ATCATCCTGCGCTCTGCGAAC }\end{array}$ & $94(40)$ & $63(45)$ & $72(60)$ & $633^{e}$ & This study \\
\hline $\begin{array}{l}\text { ESPD-F (forward) } \\
\text { ESPD-R (reverse) }\end{array}$ & espD & $\begin{array}{l}\text { CGCTGGATTTACAACTGGTTA } \\
\text { CCAGCTCAACCTTCGCACTCT }\end{array}$ & $94(40)$ & $60(45)$ & $72(60)$ & $939^{f}$ & This study \\
\hline $\begin{array}{l}\text { TIR-F (forward) } \\
\text { TIR-R (reverse) }\end{array}$ & tir & $\begin{array}{l}\text { CATTACCTTCACAAACCGAC } \\
\text { CCCCGTTAATCCTCCCAT }\end{array}$ & $94(40)$ & $57(60)$ & $72(75)$ & $1,550^{g}$ & This study \\
\hline
\end{tabular}


was subjected to a nested stx-PCR (Table 1). (The positions of the $s t x$ conserved sequence primers for stx genes are as follows: sense primer VT com-nesF, positions 395 to 413; and antisense primer VT com-nesR, positions 547 to 565.)

An oligonucleotide probe specific for both stx 1 and st $x 2$ (Table 1) (34) was synthesized and labeled with alkaline phosphatase at the 5' end by using an AP-Oligonucleotide labeling kit (Boehringer, Mannheim, Germany). The DNA probe was used to detect STEC by colony hybridization. For each stool sample 20 sorbitol-positive colonies typical of $E$. coli were picked from the SMAC plate. When sorbitol-negative coliform colonies appeared on the agar, we also picked up to 20 such colonies. The colonies were examined for the presence of any $s t x$ genes by colony hybridization techniques. All stx-positive isolates were confirmed to be $E$. coli strains by conventional biochemical tests, and if needed, API 20E and/or Micro ID techniques were employed. Then, up to three stx-positive colonies per sample were randomly chosen and subjected to classification as stx type stx 1 or stx 2 by PCR (Table 1) (18). One isolate per animal was selected for further study if all stxpositive isolates showed the same stx profile. The STEC isolates selected were characterized by PCR to determine the presence of $b f p$, the EAF plasmid, EHEC hly $A$, and the LEE genes eae, esp $A, \operatorname{esp} B, \operatorname{esp} D$, and tir (Table 1). Intimin subtyping $(\alpha, \beta, \gamma, \delta$, or $\varepsilon)$ was carried out for eae-positive isolates. All PCRs included 25 or 30 cycles of amplification with the conditions described in Table 1.

Determination of the $\mathrm{O}$-antigen group was carried out by the method described in the Denka Seiken protocol (Denka Seiken, Tokyo, Japan). A strain identified as an STEC strain was incubated on Trypticase soy agar (Difco) at $37^{\circ} \mathrm{C}$ for $18 \mathrm{~h}$. Approximately $0.3 \mathrm{~g}$ of organisms was harvested and suspended in $3 \mathrm{ml}$ of saline solution. After heating at $100^{\circ} \mathrm{C}$ for 30 min, the suspension was centrifuged at $900 \times g$ for $20 \mathrm{~min}$. The sediment was resuspended in $0.5 \mathrm{ml}$ of saline and used as the $\mathrm{O}$-antigen solution. Sera against each $\mathrm{O}$-antigen group tested were obtained from Denka Seiken and the E. coli Reference Laboratory, Universidad de Santiago de Compostela, Lugo, Spain, or were prepared at the National Institute of Animal Health, Tsukuba, Japan.

Antimicrobial susceptibility was tested by using the following 14 antimicrobial agents, most of which are commonly used for therapeutic treatment in production animals in Japan (the exceptions are ciprofloxacin and nalidixic acid): aminobenzylpenicillin, ceftiofur, dihydrostreptomycin, kanamycin, thiamphenicol, chloramphenicol, oxytetracycline, chlortetracycline, erythromycin, josamycin, colistin, nalidixic acid, ciprofloxacin, and enrofloxacin. Aminobenzyl penicillin, dihydrostreptomycin, oxytetracycline, and chlortetracycline were purchased from Wako Pure Chemical Industries, Ltd., Osaka, Japan, and the other drugs were supplied by the National Veterinary Assay Laboratory, Tokyo, Japan. In vitro susceptibility tests were carried out by the agar dilution method by using the recommendations of the National Committee for Clinical Laboratory Standards (17). Briefly, all drugs were serially twofold diluted, and $1 \mathrm{ml}$ of each dilution was mixed with $9 \mathrm{ml}$ of MuellerHinton agar (Difco). After inoculation of $10^{3}$ to $10^{4} \mathrm{CFU}$ of organisms, the plates were incubated at $37^{\circ} \mathrm{C}$ for $24 \mathrm{~h}$. The MIC was the lowest concentration of antimicrobial agent that suppressed visible bacterial growth. Two reference strains, $E$. coli NIH J2 and Staphylococcus aureus 209P, were included as internal controls in the susceptibility study. Since breakpoints for drugs used in animals have not been established, a strain was defined as resistant when its growth could not be suppressed with four times the MIC at which $90 \%$ of the isolates were inhibited or with 16 times the MIC at which $50 \%$ of the isolates were inhibited.

In this study, all stx-positive organisms isolated from cattle were identified as E. coli on the basis of biochemical properties. Therefore, an stx-PCR-positive sample was defined as STEC positive in this report. The STEC prevalence values for cows and heifers were 127 of 183 animals (69\%) and 58 of 88 animals $(66 \%)$, respectively, and thus were higher than the value for calves (40 of 87 animals [46\%]). However, nested $s t x$-PCR could detect STEC in all the samples examined. As determined by stx colony hybridization for 20 colonies per sample, we recovered $962(12.4 \%)$ STEC colonies from a total of 7,745 coliforms. Sorbitol-negative STEC were detected only rarely among the sorbitol-negative colonies (20 of 585 colonies [3.4\%]). STEC were recovered from 17 calves (20\%), 27 heifers $(31 \%)$, and 35 cows (19\%). Of 962 STEC isolates, 92 from 74 animals on 54 farms were selected and examined by serotyping, virulence factor analysis, and antimicrobial susceptibility testing. STEC were isolated by colony hybridization from 76 of $79(96 \%)$ stx-PCR-positive samples but only from 3 of 123 stx-PCR-negative samples. The latter three samples might have contained PCR inhibitors, because there were enough STEC organisms in the samples to be detected by colony hybridization.

The 92 STEC strains selected belonged to 25 different $O$ serogroups, and 18 strains were nontypeable. Only one isolate was a member of serogroup O157, and 37 of the 74 typeable isolates could be classified into five serogroups (O8, O26, O84, O113, and O116) (Table 2). A connection was found between the serogroups and the types of stx genes; all of the serogroup O26 strains contained stx 1 , whereas the serogroup O84, O113, and 0116 strains contained stx2. Another connection was found between serogroup and the presence of eae. The majority of the strains belonging to serogroups O26 (eight of nine strains), O84 (all six strains), O103 (all three strains), and O111 (both strains) contained eae and the LEE-related genes esp $A$, $\operatorname{espB}$, espD, and tir (Table 2). The serogroup O26, O111, and O157 strains, which are most frequently detected as causal agents of hemorrhagic colitis and hemolytic uremic syndrome, together accounted for more than $10 \%$ of the STEC isolates examined (12 of 92 strains). These STEC strains originated from nine farms. Thus, of $78(11.5 \%)$ of the cattle farms analyzed were reservoirs of potentially EHEC. All 92 STEC strains were negative for either $b f p$ or the EAF plasmid. The EHEC hly $A$ gene was prevalent in STEC strains; 66 of 92 $(72 \%)$ of the strains were EHEC hly $A$ positive as determined by PCR. Of the 22 eae-positive STEC strains, 16 could be intimin typed and placed in established subtypes. The eight eae-positive isolates belonging to $\mathrm{O}$ serogroup $\mathrm{O} 26$ were intimin type $\beta$, and all three $O$ serogroup $O 103$ strains were intimin type $\varepsilon$; the other eae-positive isolates were intimin type $\beta$ or nontypeable (Table 2). The only O157 isolate and the reference O157 strains were classified as intimin type $\gamma$; no intimin type $\gamma$ STEC strains were detected among the nonO157 serogroup strains (Table 2). 
TABLE 2. Characterization of 92 STEC strains isolated from cattle in Japan

\begin{tabular}{|c|c|c|c|c|c|c|c|c|c|c|c|c|c|c|c|c|c|}
\hline \multirow{2}{*}{$\begin{array}{c}\mathrm{O} \\
\text { serogroup }\end{array}$} & \multirow{2}{*}{$\begin{array}{l}\text { No. of strains } \\
\quad \text { or strain }\end{array}$} & \multicolumn{3}{|c|}{ No. of strains from ${ }^{a}$ : } & \multicolumn{11}{|c|}{ No. of strains with the following genes: } & \multirow{2}{*}{$\begin{array}{l}\text { Intimin } \\
\text { type }\end{array}$} & \multirow{2}{*}{ Antimicrobial resistance ${ }^{b}$} \\
\hline & & Calves & Heifers & Cows & $s t x 1$ & $s t x 2$ & $\begin{array}{l}\text { stx } 1 \text { and } \\
\text { stx } 2\end{array}$ & ehly $A$ & $b f p$ & $\begin{array}{c}\text { EAF } \\
\text { plasmid }\end{array}$ & eae & $\operatorname{esp} A$ & $\operatorname{esp} B$ & espD & tir & & \\
\hline $\mathrm{O} 1$ & 1 & 0 & 1 & 0 & 0 & 1 & 0 & 0 & 0 & 0 & 0 & 0 & 0 & 0 & 0 & & \\
\hline $\mathrm{O} 2$ & 1 & 0 & 1 & 0 & 0 & 1 & 0 & 0 & 0 & 0 & 0 & 0 & 0 & 0 & 0 & & \\
\hline O8 & 8 & 3 & 4 & 1 & 3 & 2 & 3 & 4 & 0 & 0 & 0 & 0 & 0 & 0 & 0 & & $\begin{array}{l}\mathrm{ABPC}+\mathrm{DSM}(1)^{c} \\
\text { OTC }+ \text { CTC }(2)\end{array}$ \\
\hline O15 & 4 & 0 & 0 & 4 & 0 & 4 & 0 & 0 & 0 & 0 & 0 & 0 & 0 & 0 & 0 & & \\
\hline $\mathrm{O} 22$ & 4 & 0 & 2 & 2 & 0 & 0 & 4 & 3 & 0 & 0 & 0 & 0 & 0 & 0 & 0 & & \\
\hline $\mathrm{O} 26$ & 9 & 4 & 1 & 4 & 9 & 0 & 0 & 6 & 0 & 0 & 8 & 8 & 8 & 8 & 8 & $\beta(8)^{c}$ & CL (1) \\
\hline $28 \mathrm{ac}$ & 1 & 1 & 0 & 0 & 0 & 1 & 0 & 1 & 0 & 0 & 0 & 0 & 0 & 0 & 0 & & \\
\hline $\mathrm{O} 38$ & 3 & 0 & 1 & 2 & 0 & 0 & 3 & 2 & 0 & 0 & 0 & 0 & 0 & 0 & 0 & & \\
\hline O55 & 1 & 0 & 0 & 1 & 0 & 0 & 1 & 0 & 0 & 0 & 0 & 0 & 0 & 0 & 0 & & \\
\hline $\mathrm{O} 73$ & 1 & 0 & 0 & 1 & 0 & 0 & 1 & 0 & 0 & 0 & 0 & 0 & 0 & 0 & 0 & & \\
\hline O84 & 6 & 1 & 1 & 4 & 6 & 0 & 0 & 6 & 0 & 0 & 6 & 0 & 6 & 6 & 5 & $\mathrm{NT}^{d}$ & \\
\hline O88 & 1 & 0 & 0 & 1 & 1 & 0 & 0 & 1 & 0 & 0 & 0 & 0 & 0 & 0 & 0 & & \\
\hline O103 & 3 & 0 & 1 & 2 & 3 & 0 & 0 & 3 & 0 & 0 & 3 & 1 & 3 & 3 & 3 & $\varepsilon(3)$ & OTC + CTC (1) \\
\hline O104 & 1 & 0 & 0 & 1 & 0 & 1 & 0 & 1 & 0 & 0 & 0 & 0 & 0 & 0 & 0 & & \\
\hline O111 & 2 & 0 & 0 & 2 & 0 & 2 & 0 & 2 & 0 & 0 & 2 & 2 & 2 & 2 & 2 & $\beta(2)$ & $\begin{array}{l}\text { DSM (1) } \\
\text { DSM + OTC + CTC (1) }\end{array}$ \\
\hline $\mathrm{O} 113$ & 8 & 3 & 2 & 3 & 0 & 8 & 0 & 5 & 0 & 0 & 0 & 0 & 0 & 0 & 0 & & \\
\hline O116 & 6 & 1 & 3 & 2 & 0 & 6 & 0 & 6 & 0 & 0 & 0 & 0 & 0 & 0 & 0 & & \\
\hline O119 & 2 & 0 & 2 & 0 & 1 & 1 & 0 & 1 & 0 & 0 & 0 & 0 & 0 & 0 & 0 & & \\
\hline $\mathrm{O} 123$ & 1 & 0 & 1 & 0 & 0 & 0 & 1 & 1 & 0 & 0 & 0 & 0 & 0 & 0 & 0 & & \\
\hline O125 & 1 & 0 & 0 & 1 & 0 & 0 & 1 & 1 & 0 & 0 & 0 & 0 & 0 & 0 & 0 & & \\
\hline O136 & 4 & 1 & 1 & 2 & 4 & 0 & 0 & 4 & 0 & 0 & 0 & 0 & 0 & 0 & 0 & & \\
\hline O153 & 2 & 0 & 0 & 2 & 0 & 2 & 0 & 2 & 0 & 0 & 0 & 0 & 0 & 0 & 0 & & \\
\hline O157 & 1 & 0 & 0 & 1 & 0 & 0 & 1 & 1 & 0 & 0 & 1 & 1 & 1 & 1 & 1 & $\gamma(1)$ & \\
\hline O158 & 1 & 0 & 0 & 1 & 0 & 1 & 0 & 0 & 0 & 0 & 0 & 0 & 0 & 0 & 0 & & \\
\hline O163 & 2 & 1 & 0 & 1 & 0 & 1 & 1 & 2 & 0 & 0 & 0 & 0 & 0 & 0 & 0 & & \\
\hline NT & 18 & 4 & 7 & 7 & 1 & 11 & 6 & 14 & 0 & 0 & 2 & 2 & 2 & 2 & 2 & $\beta(2)$ & CL (1) \\
\hline Total & 92 & 19 & 28 & 45 & 28 & 42 & 22 & 66 & 0 & 0 & 22 & 14 & 22 & 22 & 21 & & \\
\hline O157 & Fuku-07 & & & 1 & & & 1 & $+^{e}$ & - & - & + & + & + & + & + & $\gamma$ & \\
\hline O157 & Oki-04 & & & 1 & & & 1 & + & - & - & + & + & + & + & - & $\gamma$ & \\
\hline O157 & Sai-11 & & & 1 & & & 1 & + & - & - & + & + & + & + & + & $\gamma$ & \\
\hline O157 & Shizu-19 & & & 1 & & & 1 & + & - & - & + & + & + & + & + & $\gamma$ & \\
\hline O157 & $\begin{array}{l}\text { ATCC } 43889 \\
\text { (human) }\end{array}$ & & & & & 1 & & + & - & - & + & + & + & + & + & $\gamma$ & \\
\hline O157 & $\begin{array}{l}\text { ATCC } 43890 \\
\text { (human) }\end{array}$ & & & & 1 & & & + & - & - & + & + & + & + & + & $\gamma$ & \\
\hline O157 & $\begin{array}{l}\text { ATCC } 43894 \\
\text { (human) }\end{array}$ & & & & & & 1 & + & - & - & + & + & + & + & + & $\gamma$ & \\
\hline O157 & $\begin{array}{l}\text { ATCC } 35150 \\
\text { (human) }\end{array}$ & & & & & & 1 & + & - & - & + & + & + & + & + & $\gamma$ & \\
\hline
\end{tabular}

${ }^{a}$ The calves were less than 5 months old, and the heifers were between 5 and 12 months old.

${ }^{b}$ ABPC, aminobenzylpenicillin; DSM, dihydrostreptomycin; OTC, oxytetracycline; CTC, chlortetracycline; KM, kanamycin; CL, colistin.

${ }^{c}$ The numbers in parentheses are numbers of strains.

${ }^{d} \mathrm{NT}$, the strains could not be typed.

${ }^{e}+$, gene present; -, gene not present.

Only eight isolates were resistant to some of the antimicrobial drugs tested (Table 2). Six of these isolates were resistant to aminoglycosides (kanamycin and dihydrostreptomycin) and/or tetracyclines (chlortetracycline and oxytetracycline), and the other two showed resistance to colistin (Table 2). Resistance to these drugs, which are conventionally used in veterinary medicine, is common in E. coli strains from cattle. The LEE genes were found in all five drug-resistant strains which were members of $\mathrm{O}$ serogroups other than serogroup $\mathrm{O} 8$ but not in serogroup 08 strains.

In early reports workers described STEC infection rates in cattle of $8 \%$ for cows and $19 \%$ for calves in the United States (28), $17 \%$ for cows and $9 \%$ for bulls in Germany (16), and 9\% for cows and $25 \%$ for calves in Canada (32). According to these reports, remarkable differences were found in the rates of recovery of STEC isolates for adult and young animals; however, these reports were published in the first half of the 1990s. In this study we recovered STEC by colony hybridization at slightly higher frequencies (20\% for calves, $31 \%$ for heifers, and $19 \%$ for cows). Blanco et al. have reported that the STEC prevalence in Spain is 35\% for cows and 37\% for calves (5) and that there is not a significant difference between calves and cows. The use of different detection methods and the rapid development of the methods make it difficult to compare STEC prevalence rates reported for various geographic areas. For the same reason it is impossible to judge whether the prevalence rate in cattle has really increased as reflected in the reports from the last 10 years. However, the results of STEC 
screening by PCR indicate that STEC are widespread in healthy cattle in central Japan. Using nested stx-PCR, we detected stx genes from each cow. We suggest that cattle always discharge various amounts of STEC, but when the number is low, the STEC cannot be detected by $s t x$-PCR. We found that many calves were STEC positive and STEC negative as determined by stx-PCR when several samples collected at 2- to 8-week intervals were examined (data not shown).

The stx genes have been detected in members of approximately 90 to $100 \mathrm{E}$. coli $\mathrm{O}$ serogroups $(4,33)$. Most STEC strains of bovine origin seem to belong to $20 \mathrm{O}$ serogroups: $\mathrm{O} 4$, O8, O22, O25, O32, O45, O82, O84, O103, O111, O113, O116, O121, O136, O146, O153, O157, O171, O172, and OX3 (O174) $(4,22)$. The 92 STEC strains used in our study were classified into $25 \mathrm{O}$ serogroups, but only 10 serogroups (O8, O22, O84, O103, O111, O113, O116, O136, O153, and O157) were the same as the major bovine STEC O serogroups. Less than one-half of the Japanese isolates (44 of 92 isolates) belonged to these major O serogroups. Moreover, a comparison of the serogroup data for Spanish (5) and Japanese cattle showed that members of 13 of the 25 Japanese O serogroups (O1, O15, O28ac, O38, O55, O73, O88, O104, O111, O119, O123, O125, and O158) were found only in Japanese cattle. Similarly, of the 27 Spanish O serogroups, 18 (O4, O9, O20, O41, O74, O77, O78, O82, O90, O91, O92, O105, O132, O146, O150, O162, O165, and O171) were represented only by Spanish STEC strains. The distributions of $\mathrm{O}$ serogroups in cattle were thus markedly different in Spain and Japan. A comparison of cattle STEC strains from France (23) and Japan produced similar results. Based on STEC O serogroups, it seems that the cattle in Japan are isolated from the cattle in European countries in spite of the internationalization of the livestock market.

To assess the hazard of bovine STEC for human health, it is necessary to analyze a broad range of virulence-associated genes from isolates obtained from diseased humans and from cattle. Human EHEC typically possess the LEE genes together with stx (12) and sometimes the per (plasmid-encoded regulation) gene group on the EAF plasmid, which activate the LEE cassette $(11,27)$. The LEE is a gene group that is essential for microorganisms to cause AE lesions in intestinal cells (12). As most STEC strains isolated from diseased humans carry the LEE cassette (29), a detailed analysis of these genes is justified. The LEE was present in 22 of 92 STEC strains from cattle, whereas $b f p$ or the EAF plasmid could not be found in any of these strains. Organisms with the EAF plasmid seem to be isolated very rarely from cattle, as no reports have described $E$. coli isolates with the EAF plasmid from cattle samples. Moreover, no reports have described AE lesion expression of LEEpossessing $E$. coli in weaned calves or adult cattle.

As the size of the LEE cassette is $35 \mathrm{kbp}$ and the LEE cassette contains 41 predicted open reading frames (7), it is impossible to determine by molecular techniques alone whether a strain is an AEEC (including EHEC and EPEC). Therefore, observation of AE lesion expression in cell cultures is a common biological assay used to confirm the presence of AEEC (13). Although the biological assay is very important for confirming bacterial pathogenicity of a clinical sample, using this assay would be a very difficult task for epidemiological investigations because of the number of isolates to be examined. As all AE lesion-positive organisms are included among strains that possess the LEE, detecting LEE genes by a simple method such as PCR should be a very useful means of screening for epidemiological studies. In order to avoid false-negative results for LEE, we developed several PCRs to detect part of $\operatorname{esp} A, \operatorname{esp} B, \operatorname{esp} D$, and tir, genes which are essential parts of the type III secretion system of the LEE. In this study, all 22 STEC strains that possessed LEE could be detected by the eae-PCR alone. This result was confirmed by other PCRs for the LEE genes. One strain, however, was negative for $\operatorname{esp} A$, and another was negative for tir. Thus, the strains could be subtyped on the basis of their LEE genes by using the new PCR assays. We expect that these new PCRs will be useful tools for analyzing the LEE cassette.

Finally, as a method for direct detection of EHEC O157 in human samples by using multiplex PCR has been developed (22), a combination PCR for stx and intimin type $\gamma$ may be an effective prescreening method for detection of EHEC O157 in cattle fecal samples because pathogenic O157 strains always contain a type $\gamma$ eae gene in the LEE.

This work was supported by grants from the Ministry of Agriculture, Forestry and Fisheries of Japan and the Ministry of Agriculture and Forestry and the Academy of Finland.

We are grateful to Nobuyoshi Ito for excellent technical assistance.

\section{REFERENCES}

1. Adu-Bobie, J., G. Frankel, C. Bain, A. Guedes Goncalves, L. R. Trabulsi, G. Douce, S. Knutton, and G. Dougan. 1998. Detection of intimins $\alpha, \beta, \gamma$, and $\delta$, four intimin derivatives expressed by attaching and effacing microbial pathogens. J. Clin. Microbiol. 36:662-668.

2. Barret, T. J., J. B. Kaper, A. E. Jarse, and I. K. Wachsmuth. 1992. Virulence factors in Shiga-like toxin-producing Escherichia coli isolated from humans and cattle. J. Infect. Dis. 165:979-980.

3. Beutin, L., D. Geier, H. Steinruck, S. Zimmermann, and F. Scheutz. 1993. Prevalence and some properties of verotoxin (Shiga-like toxin)-producing Escherichia coli in seven different species of healthy domestic animals. J. Clin. Microbiol. 31:2483-2488.

4. Blanco, J., M. Blanco, J. E. Blanco, M. P. Alonso, J. I. Garabal, and E. A. Gonzárez. 1993. Escherichia coli enterotoxigénicos, necrotoxigénicos, y verotoxigénicos de origin humano y bovino. Servicio Publicaciones Diputación Provincial de Lugo, Lugo, Spain. (In Spanish.)

5. Blanco, M., J. E. Blanco, J. Blanco, A. Mora, C. Prado, M. P. Alonso, M. Mouriño, C. Madrid, C. Balsalobere, and A. Juárez. 1997. Distribution and characterization of faecal verotoxin-producing Escherichia coli (VTEC) isolated from healthy cattle. Vet. Microbiol. 54:309-309.

6. Boerlin, P., S. A. McEwen, E. Boerlin-Petzold, J. B. Wilson, R. P. Johnson, and C. L. Gyles. 1999. Associations between virulence factor of Shiga toxinproducing Escherichia coli and disease in humans. J. Clin. Microbiol. 37:497503.

7. Elliott, S., L. A. Wainwright, T. McDaniel, B. MacNamara, M. Donnenberg, and J. B. Kaper. 1998. The complete sequence of the locus of enterocyte effacement (LEE) from enteropathogenic Escherichia coli E2348/69. Mol. Microbiol. 28:1-4.

8. Franke, J., S. Franke, H. Schmidt, A. Schwarzkopf, L. H. Wieler, G. Baljer, L. Beutin, and H. Karch. 1994. Nucleotide sequence analysis of enteropathogenic Escherichia coli (EPEC) adherence factor probe and development of PCR for rapid detection of EPEC harboring virulence plasmids. J. Clin. Microbiol. 32:2460-2463.

9. Frankel, G., A. D. Philips, I. Rosenshine, G. Dougan, J. B. Kaper, and S. Knutton. 1998. Enteropathogenic and enterohaemorrhagic Escherichia coli: more subversive elements. Mol. Microbiol. 30:911-921.

10. Gannon, V. P. J., M. Rashed, R. K. King, and E. J. Golsteyn Thomas. 1993. Detection and characterization of the eae gene of Shiga-like toxin-producing Escherichia coli using polymerase chain reaction. J. Clin. Microbiol. 31:12681274.

11. Gómez-Duarte, O. G., and J. B. Kaper. 1995. A plasmid-encoded regulatory region activates chromosomal eaeA expression in enteropathogenic Escherichia coli. Infect. Immun. 63:1767-1776.

12. Jerse, A. E., J. Yu, B. D. Tall, and J. B. Kaper. 1990. A genetic locus of enteropathogenic Escherichia coli necessary for the production of attaching and effacing lesions on tissue culture cells. Proc. Natl. Acad. Sci. USA 87:7839-7843.

13. Knutton, S., T. Baldwin, P. H. Williams, and A. S. McNeish. 1989. Actin accumulation at sites of bacterial adhesion to tissue culture cell: basis of a 
new diagnostic test for enteropathogenic and enterohemorrhagic Escherichia coli. Infect. Immun. 57:1290-1298.

14. Levine, M. M., and R. Edelman. 1984. Enteropathogenic Escherichia coli of classic serotypes associated with infant diarrhea: epidemiology and pathogenesis. Epidemiol. Rev. 6:31-51.

15. Mellies, J. L., S. J. Elliot, V. Sperandio, M. S. Donnenberg, and J. B. Kaper. 1999. The Per regulon of enteropathogenic Escherichia coli: identification of a regulatory cascade and a novel transcriptional activator, the locus of enterocyte effacement (LEE)-encoded regulator (Ler). Mol. Microbiol. 33: 296-306.

16. Montenegro, M. A., M. Bulte, T. Trumpf, S. Aleksic, G. Reuter, E. Bulling, and R. Helmuth. 1990. Detection and characterization of fecal verotoxinproducing Escherichia coli from healthy cattle. J. Clin. Microbiol. 28:14171421.

17. National Committee for Clinical Laboratory Standards. 1997. Methods for dilution antimicrobial susceptibility testing for bacteria that grow aerobically. Approved standard M7-A4. National Committee for Clinical Laboratory Standards, Wayne, Pa.

18. Olsvik, O., and N. A. Strockbine. 1993. PCR detection of heat-stable, heatlabile and Shiga-like toxin genes in Escherichia coli, p. 271-276. In D. H. Persing, T. F. Smith, F. C. Tenover, and T. J. White (ed.), Diagnostic molecular microbiology. American Society for Microbiology, Washington, D.C.

19. Oswald, E., H. Schmidt, S. Morabito, H. Karch, O. Marcès, and A. Caprioli. 2000. Typing of intimin gene in human and animal enteropathogenic and enterohemorrhagic Escherichia coli. Infect. Immun. 68:64-71.

20. Paton, A. W., and J. C. Paton. 1998. Detection and characterization of Shiga toxigenic Escherichia coli by using multiplex PCR assays for $s t x_{1}, s t x_{2}$, eaeA, enterohemorrhagic $E$. coli $h l y A, r f b_{\mathrm{O} 111}$, and $r f b_{\mathrm{O} 157}$. J. Clin. Microbiol. 36:598-602.

21. Paton, A. W., R. M. Ratcliff, R. M. Doyle, J. Seymour-Murray, D. Davos, J. A. Lancer, and J. C. Paton. 1996. Molecular microbiological investigation of an outbreak of hemolytic-uremic syndrome caused by dry fermented sausage contaminated with Shiga-like toxin-producing Escherichia coli. J. Clin. Microbiol. 34:1622-1627.

22. Pohl, P. 1991. Les Escherichia coli verotoxigènes isolées des bovines. Ann. Med. Vet. 135:569-576.

23. Pradel, N., V. Liverelli, C. Champs, J. Palcoux, A. Reynaud, F. Scheytz, J. Sirot, B. Joly, and C. Forestier. 2000. Prevalence and characterization of Shiga toxin-producing Escherichia coli isolated from cattle, food, and children during a one-year prospective study in France. J. Clin. Microbiol. 38:1023-1031.
24. Reid, S. D., D. J. Betting, and T. S. Whittam. 1999. Molecular detection and identification of intimin alleles in pathogenic Escherichia coli by multiplex PCR. J. Clin. Microbiol. 37:2719-2722.

25. Riley, L. Q., R. S. Remis, S. D. Helgerson, H. B. McGee, J. G. Wells, B. R. Davis, R. J. Herbert, E. S. Olcott, L. M. Johnson, N. T. Hergrett, P. A. Blake, and M. L. Cohen. 1983. Hemorrhagic colitis associated with a rare Escherichia coli serotype. N. Engl. J. Med. 308:681-685.

26. Smith, H. R., and S. M. Scotland. 1988 . Vero cytotoxin-producing strains of Escherichia coli. J. Med. Microbiol. 40:3-9.

27. Tobe, T., G. K. Schoolnik, I. Sohel, V. H. Bustamante, and J. L. Puente. 1996. Cloning and characterization of $b f p T V W$, genes required for the transcriptional activation of $b f p A$ in enteropathogenic Escherichia coli. Mol. Microbiol. 21:963-975.

28. Wells, J. S., L. D. Shipman, K. D. Greene, E. G. Sowers, J. H. Green, P. N. Cameron, F. P. Downes, M. L. Mantin, P. M. Griffin, S. M. Ostroff, M. E. Potter, R. V. Tauxe, and I. K. Wachmuth. 1991. Isolation of Escherichia coli serotype O157:H7 and other Shiga-like toxin-producing Escherichia coli from dairy cattle. J. Clin. Microbiol. 29:985-989.

29. Whittam, T. S. 1998. Evolution of Escherichia coli O157:H7 and other Shiga toxin-producing E. coli strains, p. 195-209. In J. B. Kaper and A. D. O'Brien (ed.), Escherichia coli O157:H7 and other Shiga-toxin-producing E. coli strains. American Society for Microbiology, Washington, D.C.

30. Wieler, L. H., E. Vieler, C. Erpenstein, T. Schlapp, H. Steinruck, R. Bauerfeind, A. Byomi, and G. Baljer. 1996. Shiga toxin-producing Escherichia coli strains from bovines: association of adhesion with carriage of eae and other genes. J. Clin. Microbiol. 34:2980-2984.

31. Willshaw, G. A., T. Cheasty, B. Jiggle, B. Rowe, D. Gibbons, and D. N. Hutchinson. 1993. Verocytotoxin producing Escherichia coli in a herd of daily cattle. Vet. Rec. 132:96.

32. Wilson, J. B., S. A. McEven, R. C. Clarke, K. E. Leslie, R. A. Wilson, D. Waltner-Toews, and C. L. Gyles. 1992. Distribution and characteristics of verocytotoxigenic Escherichia coli isolated from Ontario dairy cattle. Epidemiol. Infect. 108:423-439.

33. World Health Organization. 1997. Consultation on the prevention and control of enterohaemorrhagic Escherichia coli, p. 39. World Health Organization, Geneva, Switzerland.

34. Yamasaki, S., Z. Lin, H. Shirai, A. Terai, Y. Oku, H. Ito, M. Ohmura, T. Karasawa, T. Tsukamoto, H. Kurazono, and Y. Takeda. 1996. Typing of verotoxins by DNA colony hybridization with poly- and oligonucleotide probes, a bead-enzyme-linked immunosorbent assay, and polymerase chain reaction. Microbiol. Immunol. 40:345-352. 